\title{
6. FA ÉS FELDOLGOZÁSA
}

\section{A KOMMANDó-KovÁSZNA SIKLÓPÁLYA}

Hivatalos források szerint a Kommandó ${ }^{1}-K_{\text {Kovászna }}{ }^{2}$ siklóvasút a franciaországi Lyon és a magyarországi budavári sikló után a harmadikként épült Európában ${ }^{3}$ (Rosta István 1995). Sajtóinformációk szerint ez volt az egyedüli kitérőkkel épült gravitációs siklópálya, amely a legtovább üzemelt (1999. nov. 1.) jelentősebb átalakítás nélkül. Okkal állíthatjuk, hogy ez a szerkezet a 19. század mérnöki zsenialitásának egyik remeke, amely relatív 400 méteres szintkülönbséget leküzdve egy szédítően magas hegyen, kitérőkkel ellátva múködött. Valamikor sok hasonló siklópálya létezett, de ez élt a legtovább, ezért vitathatatlan, hogy európai szinten egyedi ipartörténeti müemlék lehetne, ha megőriztük volna. A kommandóiak szemszögéből nézve közel 110 évig a sikló létfontosságú szerkezet volt, hiszen rajta szállították le és fel a rönköket, a szelvényárut, az élelmet, a gépeket, az utasokat, postai küldeményeket, pénzt, beteget, egyszóval mindent. A helybeliek sokáig csuszlónak nevezték, ez a népies megnevezés ma a múlt emlékei közé tartozik, és sajnos, lassan a szerkezet is oda kerül. A siklót Horn Dávid ${ }^{4}$ építette, majd a tulajdonosváltás után Groedelék ${ }^{5}$ tökéletesítették, úgy, hogy hozattak Bécsből egy kerekes fékezős álló szerkezetet. Gyakorlatilag a kerekes gépezettel együtt ismert a formája, működése. Tény, hogy 1890-től 1999-ig ez adott munkalehetőséget az évek hosszú során több száz munkásnak, akik közül sokan napjainkban is könnyes szemmel mesélnek azokról az évekről, amikor a siklói személyzet körébe tartoztak.

\section{A siklópálya szerkezete, működése}

Előzetesen olvassuk el a szerkezetről azt a leírást, ami különlegességnek számít:

„Térrét-Gyulafalvi ${ }^{6}$ sikló, tervezte Lux Emil, épült 1888-1890-ben, építette: Horn Dávid budapesti faiparos, tulajdonosa: Erdélyi Erdôipar Rt, az építkezési/kivitelezési munkálatokat Lux Emil és Tuñsek Pál vasúti mérnökök vezették." (M.O.L. 1891. P.111. A /4, 12,7fm.)

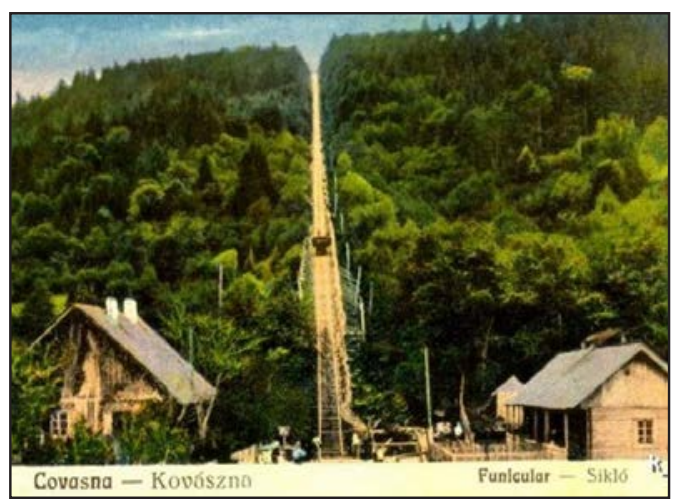

1. kép. A siklóópálya legszebb fotója (1925-ös felvétel) 
Az alábbiakban közöljük a szerkezetről azt a leírást, amit napjainkban, többnyire minden írott forrásban megtalálunk. Ez a leírás egykor ki volt függesztve a siklótetőn a gépházban. Állítólag még az 1960-as években is ott volt. Az eredeti nem tudni hogyan, de eltűnt, mert 1983-ban - Drunek igazgató idején - a vasutasok feldíszített mozdonynyal, állványkocsival ${ }^{7}$, ünnepi díszbe öltözve, fúvószenekarral tartott ünnepség keretében (7 évvel korábban) megtartották a 100 éves évfordulót. Viszont akadt olyan ember, aki lemásolta és megőrizte a leírást, mert 2004-ben Péter János (szül. 1953) kommandói adatközlő jóvoltából hozzám került. Íme, a másolat:

„Kovászna - Kommandó siklópálya, tervezte Lux Emil, épült 1888-1890, építette az Erdélyi Erdőipar Rt. A dán gyártmányú sikló adatai:

*Hossza: 1268 m

*Az állványkocsik nyomtávolsága: 1445 mm

*A felső állomás tengerszinttől számított magassága: $1013 \mathrm{~m}$

*A középső állomás tengerszinttől számított magassága: $853 \mathrm{~m}$

*Az alsó állomás magassága: 686 m

*A felső szakasz emelkedése: 268\%o
*Az alsó szakasz emelkedése: $280 \%$ o

*Menetidő: 15 perc

*Szintkülönbség siklóalja és siklótető között: $327,7 \mathrm{~m}$

*Az 1236 m hosszú sínpáron két állványkocsi található, amelyeket egy $28 \mathrm{~mm}$-es acélkötél köt össze. Az acélkötél 6 ágból áll, minden ág 19 különböző méretü drótból áll: 1.- 2,7 mm; 2.- 2,3 mm; 3.-1,3 mm, összesen: 114 szál drót.

*Szakítási próba: 54000 kgs.

*A gépezet: TH OBACH / Masinenfabrik Wien

*A pálya lejtése: 28 - 40 fok." (Szabó Mária 2004. 45-46.) (1. és 2. ábra Péter Klára dolgozatából)

Mivelhogy ez a szerkezet egyedinek számított, s a későbbiekben a folyamatos javítások, felújítások, siklótüzek és különböző változtatások miatt az idők során többször módosítottak rajta, úgy véljük, hogy fontos az első, pontos szakirodalmi leírás közlése mind a gépezet összetételéről, mind annak a működéséről. Az első leírást a frissen tökéletesített siklópálya szerkezetéről, működéséről, a kötelekről és a sínekről Sümegh Ignác 1898-ban tette közzé az Országos Erdészeti Egyesület közlönyében, az Erdészeti Lapokban.

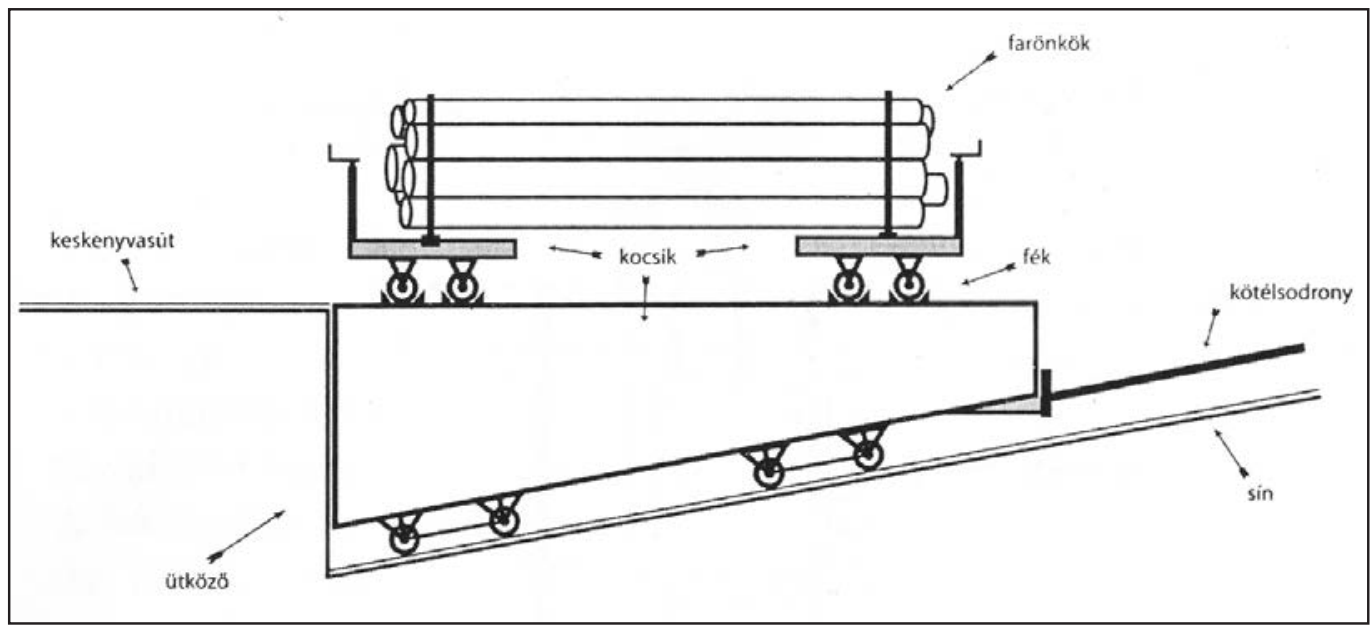

1. ábra. Vázlatrajz az állványkocsiról (Péter Klára dolgozata) 


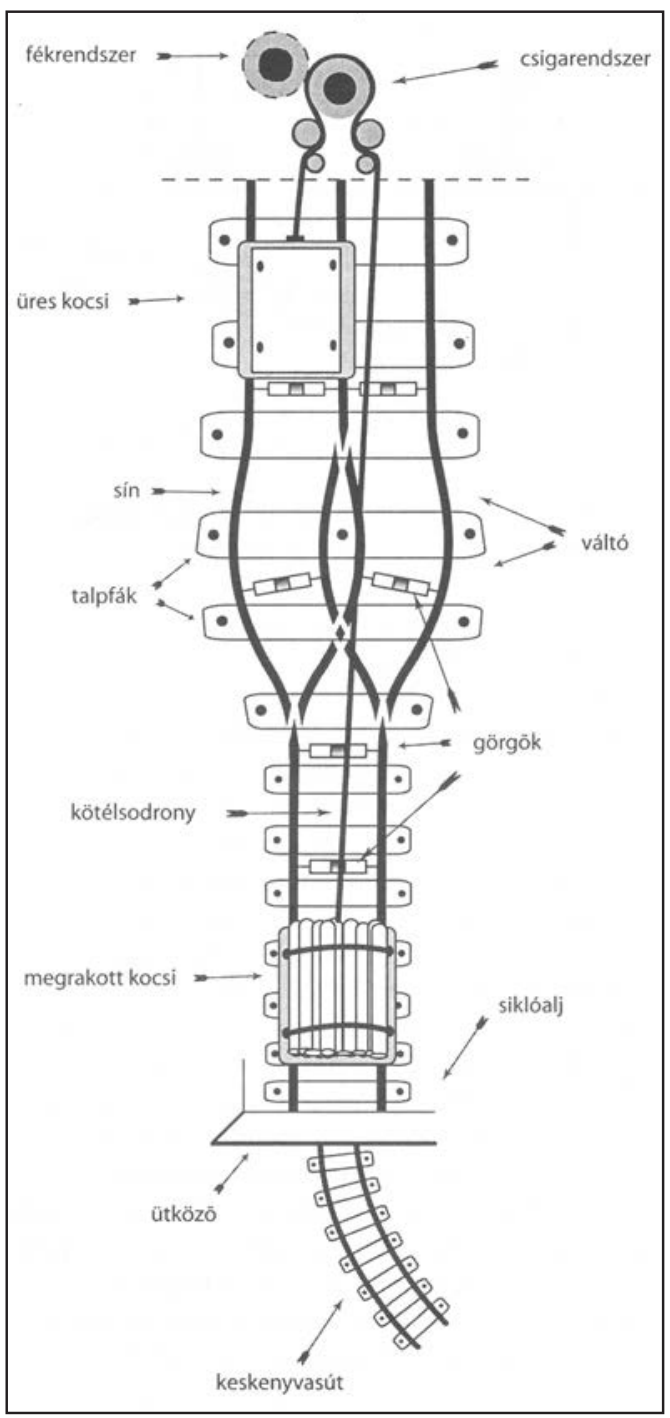

2. ábra. A sikló múködése (Péter Klára dolgozata)

„A sikló szerkezete Th. Obach bécsi cégtől származik. A vállalat a siklót kisebbített méretében szerkesztve az ezeréves kiállításon bemutatta. A sikló förészeit képezik: a) siklópálya, b) a felsősiklón alkalmazott gépezet, melynek főbb részei a kötéldobok és fémkorongok, c) siklókötél, d) két sikló-állványkocsi, melyekre az üres, ill. a megrakott kocsikat kell rátolni. A pálya hossza 1258 m. Legnagyobb esés-emelkedés: 345\%o, legkisebb esés-emelkedés: 220\%o, átlag esés-emelkedés: 268\%o. A sínek Bessemer-acélból készültek, súlyuk folyóméterenként 15,7 kg. Nyomtáv normális 1,435 méter. A sikló viszonylagos magassága 328,54 méter. Minthogy a teher felülrôl lefelé szállíttatik, erőfejlesztő gép teljesen szükségtelen, és a sikló a ferde síkon való esés törvényén alapszik, a kötél felső végéhez a teherkocsi, alsó végéhez pedig az üres kocsi van erôsítve. A kötél a sikló felső részén elhelyezett dobokra úgy van körülcsavarva, hogy a jobb oldali dobról 3-4 szeres körültekeredés után egy merőleges tengelyú vízszintesen forgó kerékdobra, onnan egy bal oldali kerékdobra csap át, erre ismét 3-4 szeresen feltekeredik. A kötélnek a bal oldali dobon túl haladó vége a megterhelt sikló állványkocsihoz köttetik. A teherkocsi kikötése esetén, önsúlya következtében lefelé haladván, forgásba hozza a kötéldobokat és húzza fölfelé az üres kocsit. A siklókocsi sebessége a dobokhoz alkalmazott, előbbieket körülfoglaló fémkorongok össze, vagy széthúzással szabályozható. [...] A sínek Bessemer acélból készültek, súlyuk folyóméterenként $15,7 \mathrm{~kg}$, a nyomtáv normális. [...] A vállalat eddig kétféle szerkezetű siklókötelet alkalmazott, az Obach félét és a Wakefieldi George Crafdock félét. Az Obach-féle kötél áll: 114 szál 1,6 mm vastag tégelyacél sodronyból és úgy van szerkesztve, hogy a 114 szál sodrony 6 kötegre osztva egy kenderbél körül van fonva. A kötél $25 \mathrm{~mm}$ vastag, és súlya folyóméterenként 2,08 kg. Mindegyik sodrony keresztmetszete 2,01 $\mathrm{mm}^{2}$. E szerint tehát az egész kötélnek keresztmetszete 002,01 $\mathrm{mm}^{2} \times$ $114=229 \mathrm{~mm}^{2}$. A kötélanyag a legkitünőbb tégelyacélból áll és $1 \mathrm{~mm}^{2}$-kint $180 \mathrm{kilog}$ ramm ellenálló képességgel bír, tehát a kötél ellenálló szilárdsága $229 \times 180=41.220 \mathrm{~kg}$. A megterhelt sikló állványkocsi súlya mintegy $13.000 \mathrm{~kg}$. És a siklópálya (hosszmetszetének 
átalakítása elött) legnagyobb esése 410\%o volt. A kötélhúzó feszültsége $4940 \mathrm{~kg}$. Ez a feszültség a rendes üzemnél mutatkozik, mely azonban vigyázatlan gyors fékezés folytán $9000 \mathrm{~kg}$-ra is emelhetô. Ez utóbbi esetben a kötél biztonsága 41.220 : $9000=4,59$ azaz a kötél 4,59 szoros biztonsággal bír. Az angol kötélnek következő a szerkezete: áll 6 kötegböl, mindegyik 7 belső 1,2 mm és 8 külső 2,3 mm vastag tégelyacél sodronyból, tehát összesen 90 sodronyból kátrányozott kenderbéllel. A kötél átméröje $27 \mathrm{~mm}$, súlya $30.000 \mathrm{~kg}$, ezzel a kötéllel 10.000-11.000 kocsi lebocsátható. A vasúti kocsik közül kétféle van alkalmazásban 5000 és $6000 \mathrm{~kg}$ raksúllyal, e szerint a fürészárukból 10-12 $\mathrm{m}^{3}$ rakható. Naponta 50-55 kocsi ereszthetôl le, ami 400-450 $\mathrm{m}^{3}$ szelvényárunak és 5-10 kocsi bükkárunak felel meg." (Sümegh Ignác 1898. 1009-1010.)

Az alábbi ismertető a sikló működésének utolsó 55 éves időszakáról (1944-1999) forrásmunkák és az adatközlők - javítók, karbantartók, utazószemélyzet, munkások visszaemlékezései alapján készült.

A sikló vasútpályája tulajdonképpen két részre osztható, az alsó és felső pályára, amiket a középállomás választ el egymástól. A felső pálya háromsínes rendszerű, amelyből a középső sínszálat mindkét állványkocsi használja. Az alsó pálya hagyományos kétsínes. A középállomás félkör alakú sínpárokkal van kiépítve, a völgy felőli részén található a kocsikísérők által állított váltó, a hegy felőli részen a belső sínszálak összefonódásával alakult ki a háromsínes vágány. A sikló felső állomásához kapcsolódva, a kocsik rendezéséhez 4 vágányos végállomást építettek, melyből kettő fut be az állványkocsikhoz. Innen indul a kisvasút felső $10 \mathrm{~km}$ hosszú fővonala Kommandóra (Nagy Jenő 2002. 10.).

Az állványkocsi, amely a siklótetőtől a sikló aljáig közlekedik, két részből áll: az alvázból és a fedélzetből. Az alváz vasból készült, és négy keréken mozog. Az alsó két kerék nem illeszkedik közvetlenül a vázhoz, csak vasrudak segítségével, s ez biztosítja, hogy a fedélzet mindig biztonságosan álljon. A fedélzet vastag pallódeszkából készült, a szélén vaskorlát van, a közepén pedig sínpár, ugyanis erre húzzák rá ló segítségével a kocsikat. Az egész építményt acélkötél tartja, s ezért a két vasúti sín között rolnik ${ }^{8}$ vannak, amelyeken a kötél gördül. Ha a kötél a földön csúszna, nagyon gyorsan elkopna (elmondta Biloklávek Mátyás).

Az állványkocsikra széles talpú síneket szereltek, amelyeket széles fém alátétlemezekkel és tirefon ${ }^{9}$ csavarokkal fogattak fel a talpfákra.

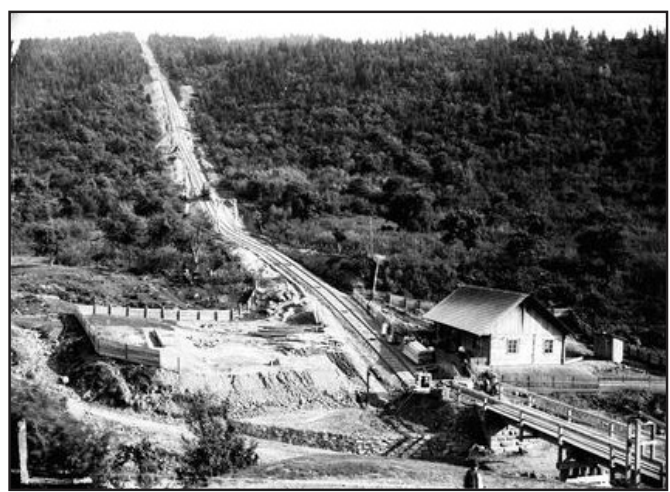

2. kép. Ismert felvétel a régi siklóról (Adler L.,1924.)

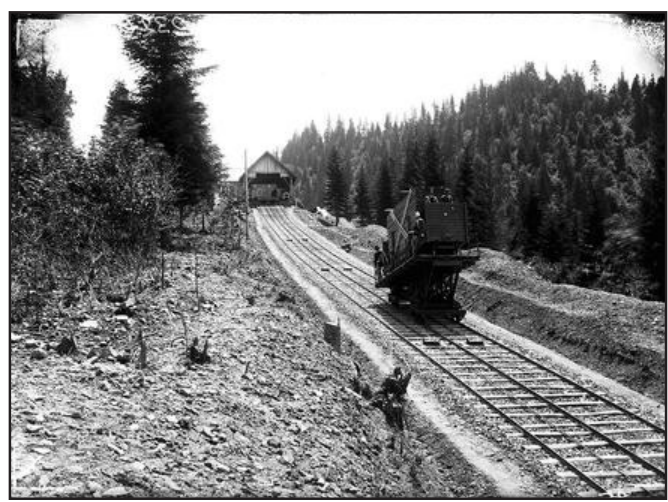

3. kép. Kovászna-Kommandó gravitációs siklópálya (archív felvétel) 
Fontos volt a sínszerkezet stabilítása és keménysége, ellenkező esetben nem bírta volna meg a rakományt. A góri siklónál ${ }^{10}$ még ennél is szélesebb volt a sínek talapzata, ezeket góri sínnek vagy talpas sínnek ${ }^{11}$ nevezték, ugyanis itt nem volt állványkocsi, és ilyen talpas sínekből állt az egész siklópálya. Az emlékek szerint még a kommunista rendszerben is volt arra példa, hogy ilyenekből javították ki a kovásznai siklón az állványkocsi sínszerkezetét. Sajnos, hogy még az ilyen talpassín-maradványokat is eladták ócskavasnak (elmondta Biloklávek Mátyás).

A két állványkocsira fel volt szorítva az acélkötél, amely a sínpár közepén vezetett végig. A kötelet kívül öntvény, belül rézgörgők segítségével rögzítették. Körülbelül 200 darab kisebb-nagyobb rézgörgő volt a siklópályán, amelyek pörögtek menet közben, és megadták a kocsik sebességét, azonkívül ezek védték a kötelet az esőtől, hótól, sártól. A szálak központi része a tetőn felállított gépházban volt. A sikló az egyensúly alapján működött. Motorra és üzemanyagra nem volt szükség, mert a vontatáshoz szükséges energiát a megrakott kocsi adta, a terhelt kocsi egyszerűen kihúzta a völgyből az üreset. A sebességet fékrendszerrel szabályozták, volt olyan eset is, hogy füstölt a rendszer, mert a nagy sebességtől és a súrlódástól felhevült, ilyenkor vízzel locsolták (elmondta Biloklávek Mátyás).

A csuszló „szívéről”, vagyis a kerekes szerkezet későbbi működéséről olvassuk el az adatközlésen alapuló ismertetőt.

A gépházban a szerkezet alatt volt egy jókora pincehelyiség, ahová lépcsőn lehetett lemenni. A pince csapóajtóval volt ellátva, ezt csak akkor tartották nyitva, amikor dolgozott az álló szerkezet. A látvány lenyűgöző volt. Középen egy hatalmas vízszintes állású csillagkerék forgott, ez öntvényből készült, és hasonlított a gőzgép lendkerekéhez, egyszerü, vájat nélküli, sima kerék, amely körülbelül 5 tonnát nyomott, rá volt szerelve hat darab félhold alakú acéldob, ezek vájatokkal voltak ellátva, ugyanis a kötél ide volt bevezetve. Az acéldobok egyenként másfél mázsát nyomtak. Ezt a központi kereket dobkeréknek vagy csillagkeréknek nevezték.

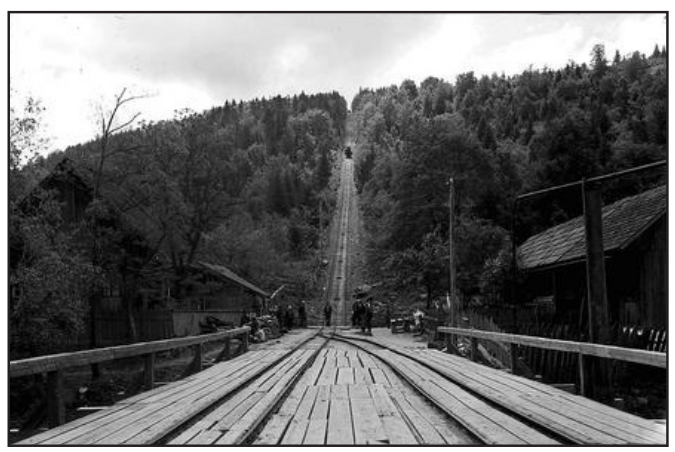

4. kép. Alsósiklón a híd 1924-ben

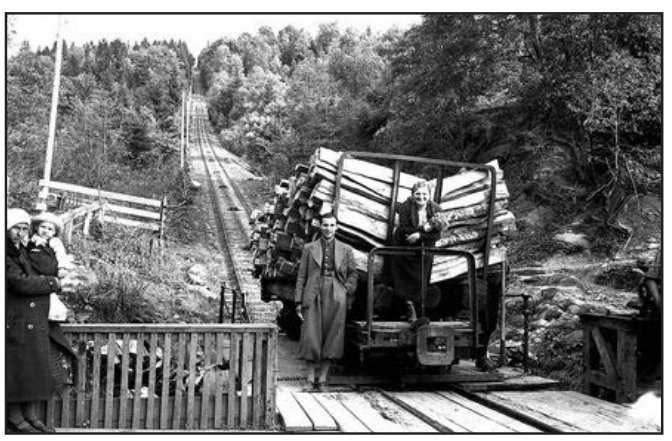

5. kép. Rakott állványkocsi (1924)

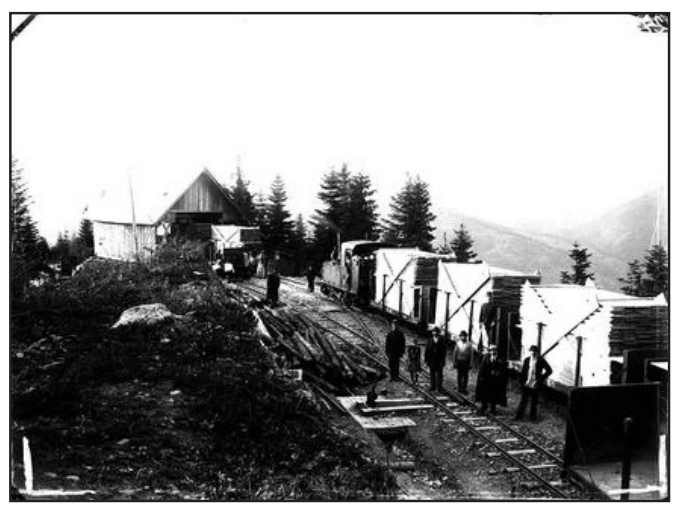

6. kép. Rakott kocsik a siklótetőn (archív felvétel) 
„Tegnap nyílt meg a Kovászna-Térrét-Gyulafalvi iparvasút, melyet Horn Dávid és társai építettek a papolci határban fekvő fenyöerdők kihasználása végett. Szavahihető emberek szerint széles e hazában, sôt azonkívül is messze körben ritkítja párját ezen merész és mégis kitünően sikerült vállalat, legföképpen pedig annak vasúti része. Kovásznán felül a Horgász nevü gyógyforrás közelében levő Térrét nevü helyrôl indul a pálya. Kezdetben pár kilométernyi síkságon halad át. Azután 1870 méter hosszan egy szédítöen meredek oldalon, melybe 345 m magas sodronykötél által vont sikló van beiktatva olyanképpen, hogy a terhelt kocsi felülről jőve saját súlyával felhúzza alolról az üres kocsit olyanképpen, hogy a két kocsi középen találkozva az e célra berendezett készülék segítségével kitér egymás elől. Azután újból rendes pálya következik, mintegy odaragasztván a meredek kősziklaoldalhoz, gyönyörü kilátást nyitva a szép háromszéki síkságra. Végül a fenyvesek végeérhetetlen tömkelege jön, szebbnél szebb allékat képezve a helyenként nyílegyenesen haladó pálya két oldalán, míg végre a „Gábor-fürész " nevü felső telephez ér, ahol egy egész kis helység képződött alig egy év leforgása alatt. Ezen áthaladva újból gyönyörü síkságon halad tovább, mindig és mindig fenyvesek között a Nagy-Baszka-patak bal partján a Györke-patak torkolatáig, hol a »József-fürész «fekszik, melyet közel két évvel ezelött avatott fel közönségünk lelkes öröme és részvétele között az akkor még egyedüli Horn Dávid tulajdonos[...] Azután következett a beszentelés [...] a beszolgáló zágoni róm. kat. lelkész és a kovásznai református, evangélikus és görögkeleti lelkészek tartották meg azt a villanyfénnyel világított gépházban az összes vendégek és gyári munkások jelenlétében, majd a Gábor-fürész feletti magaslaton álló vendégszálló villa éttermében folytatódott az ünnepség."

(Székely Nemzet 1889.3.)
A visszaemlékezők szerint a csillagkerék egy darabból állt, és valamikor lovakkal vontatták fel a siklótetőre a pályatest melletti rövidítő útszakaszon, amelyet később az utasok is használtak, ha nem engedték felszállni őket a siklóra. A kereket egyesek „vájat nélküli keréknek" is nevezték (elmondta Biloklávek Mátyás).

A dobkerék alá fel volt szerelve az orsósfék muffal ${ }^{12}$ ellátva, és a tengely acélból volt öntve, a forgórész csapágyai valamikor bronzból voltak esztergálva, később a bronzot rézzel helyettesítették (ezen forgott a dobkerék). A dobkerék mellett még volt két kisebb függőleges fekvésű fogaskerék, jobb és bal oldalon: a bevezető és kivezető kerék, ezeken volt keresztülvezetve a kötél, s a kerék rakta egymás után a kötelet a százötven kilós dobokra, amelyekbe be volt vezetve a kötél. A bevezető kerékről ment a kötél a dobkerékre kétszer megcsavarodva, hogy fékezéskor ne csússzon, egyszer bejött onnan a fordítókerékre, tehát bal oldali kerék, dobkerék, jobb oldali és vissza a kivezető kerékre. A bevezető és kivezető kerekekre voltak felszerelve a különböző drótterelő szerkezetek, valamint itt voltak a siklócsapágyas csigák is (elmondta Péter János).

A dobkerék szélére volt felvezetve $2+2$ fékcsintura ${ }^{13}$, erre jöttek rá a szilfatuskók ${ }^{14}$. 32 darab ilyen szilfa féktuskó volt egy-egy fékcsinturán. A fék tolatószerkezetéhez (hátramenethez) réz, majd elkopás után vas csapágyak járultak hozzá. A kötél vastagsága 30 mm. Egy új kötél 22000 kocsit bírt meg cserélés nélkül, és $25 \mathrm{~mm}$-ig volt szabad elkopnia. A dob átmérője, ahova a kötél jön, 1550 mm, a féké 2010 mm, a csinturák háza 8 darab 7/8-as csavarral volt rögzítve. A fordulatszám matematikai számítás szerint: $1550 \times 3,14=4,887 \mathrm{~m} / \mathrm{m}$ - fordulat, vagyis 267-et fordult egy kurszában ${ }^{15}$. Súlykülönb- 
ség $6500 \mathrm{~kg}$, felül $12000 \mathrm{~kg}$ a pőrekocsi ${ }^{16}$ súlyán kívül. A kötél szakítószilárdsága 55000 kg. Érdekességként eláruljuk azt a titkot is, hogy a kötél közepébe csihányspárga ${ }^{17}$ volt belefonva, azért, hogy a dobra csavarodva a dob ne vágja el. Az állványra helyezett kocsi hossza 6,30 m (ekkora volt a rajta levő sínpár), a rönk vagy a rakomány lehetett hosszabb. Az adatközlők szerint a dobfalak 1942-ben és 1981-ben voltak kicserélve. A fából készített sámlik csúszásgátló szerepet töltöttek be (elmondta Ferencz János és Jenei Gyula).

Ha már kikopott, a kötelet lecserélték, de általában nyáron szükséges volt vízzel locsolni, hogy a nagy súrlódástól felmelegedett kötél nehogy meggyúljon. A fékorsó végétől lánc jött fel a kormánykerekekre, amelyen két mánus ${ }^{18}$ volt, ami mutatta a kocsik helyzetét. A vezérmű két darab, hajókormánykerékhez hasonló fogantyús kerék segítségével múködött, ezek egymással párhuzamosan voltak felszerelve. Az acéldobokat négyszög alakú szilfából készült sámlival ${ }^{19}$ (fékcsintura, féktuskókkal) biztosították le, ezeket fékpofáknak nevezték, amelyek a felső kerekek szorításával, illetve lazításával fékezték vagy engedték a kocsit. Az adatközlő szerint - aki valamikor a gépészt helyettesítette - azért volt két fékcsintura, mert mindkét felső kormánykeréknek külön-külön megvolt a saját szerkezete, az egyik kerék a felső állványkocsi, a másik az alsó állványkocsi irányítására szolgált. Rendszeresen az alsó kocsit irányító kereket eléfelé hajtották, vagyis eresztették a kocsit, mert a felső kocsi a gravitációnak megfelelően önsúlyától fogva lejtőre jobban ment, ezt a kereket inkább szorították, de volt olyan eset is, hogy mindkettőt visszafelé kellett húzni, vagyis fékezni kellett, mert nem volt szabad túl gyorsan engedni a kocsikat, hiszen nagyon könnyen elszabadulhatott a pokol (elmondta Biloklávek Mátyás és

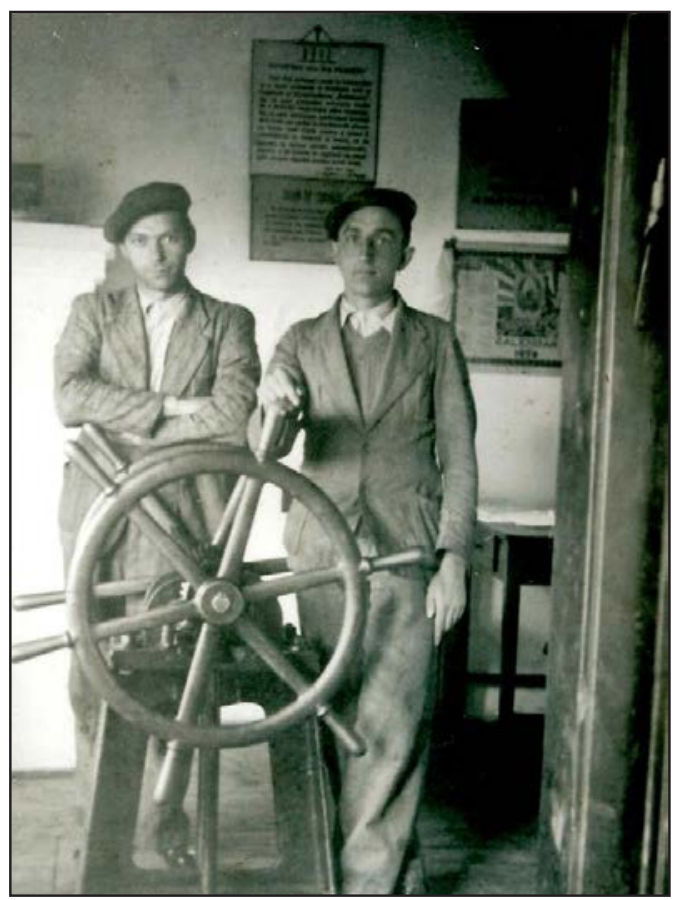

7. kép. A gépház az 1930-as években, Jenei Gyula és Fejér András

Jeney Gyula).

A szerkezet gépésze - a siklópálya legfontosabb személye - a nyitott pincéből látta a szerkezet múködését, a mánusok mutatták a kocsik helyzetét, s a lánc pörgéséről tudta, hogy mikor kell szorítani, illetve lazítani a kerekeket. Ha könnyű volt a kocsi, többször kellett fékezni, ha nehezebb, kevesebbszer. Ha a kötél megnyúlt a nagy súlytól, a pincében vágtak ki belőle. Leszerelték a felső kocsiról, és megrövidítették, majd újrafonták a kibomlott részt, ehhez Bandi bácsi (Fejér András) értett a legjobban. Az acéldobokat a kikopás után újjal cserélték ki, és a selejtezettekre kétfelől fogantyút hegesztettek, ezekből készült a dobfal (aggfal), amelyet ellensúlynak használtak. Valamikor 40 darab ellensúlyt tartottak a siklótetőn. Lehet, ma már egyet sem találnánk meg belőlük (elmondta Biloklávek Mátyás). 
Az alsó siklót és a tündérvölgyi vasúti szakaszt egy merész patakvölgy választotta el egymástól. Ezt a részt egy gerendákból és pallókból készült híddal kötötték össze, aminek a közepén vasúti sínpár helyezkedett el. A könynyűszerkezetű híd hossztartói, kereszttartói rönkből készültek, és az ívviszonyok miatt csak lóvontatással vagy emberi erő segítségével lehetett a kocsikat továbbítani. A kovásznai hídfőnél volt a Térrét vasúti állomása.

Az évek során nagy hangsúlyt fektettek az sikló alatti híd karbantartására, mert ez képezte a fő kapcsot a sikló és a vaspálya között. A szokásos kopáson kívül sokszor volt árvíz vagy tűzeset, ami miatt újra kellett a hidat építeni (nagyon sok színes felvételen látszik az új híd), 1999-től, vagyis miután a siklópálya leállt, a híddal sem törődött senki, folyamatosan romlott, végül 2006 tavaszán a Kovászna-pataka ismét megáradt, és elvitte a maradványokat is.

\section{A siklópálya üzemeltetése és karbantartása}

A sikló üzemeltetéséhez külön személyzet tartozott. Állványkocsinként két fő, továbbá a felső állomáson egy gépkezelő, aki egyben a telefont is kezelte, 2 revizor, 2 fékező, 4-6 tolató és pályamunkás. Az alsó siklón egy forgalmista, 2 revizor, 2 fékező, 4- 6 tolató és pályamunkás. Az 1970-es évektől a személyzetet lassan leépítették, az utolsó években összesen 10 fó dolgozott a siklón.

Az állványkocsik személyzete (a tolatók) a következő feladatokat látta el: a lovak és lószerszámok gondozása (esetleges patkolása is), a tolatási műveletek elvégzése. Mind a felső, mind az alsó siklón volt ló és lóistálló. A húzató lovak általában apró, mokány termetű vagy herélt, béketűrő állatok voltak. A legendás fehér lovat - számtalan fotón látható - a magyarok Jancsinak, a román munká-

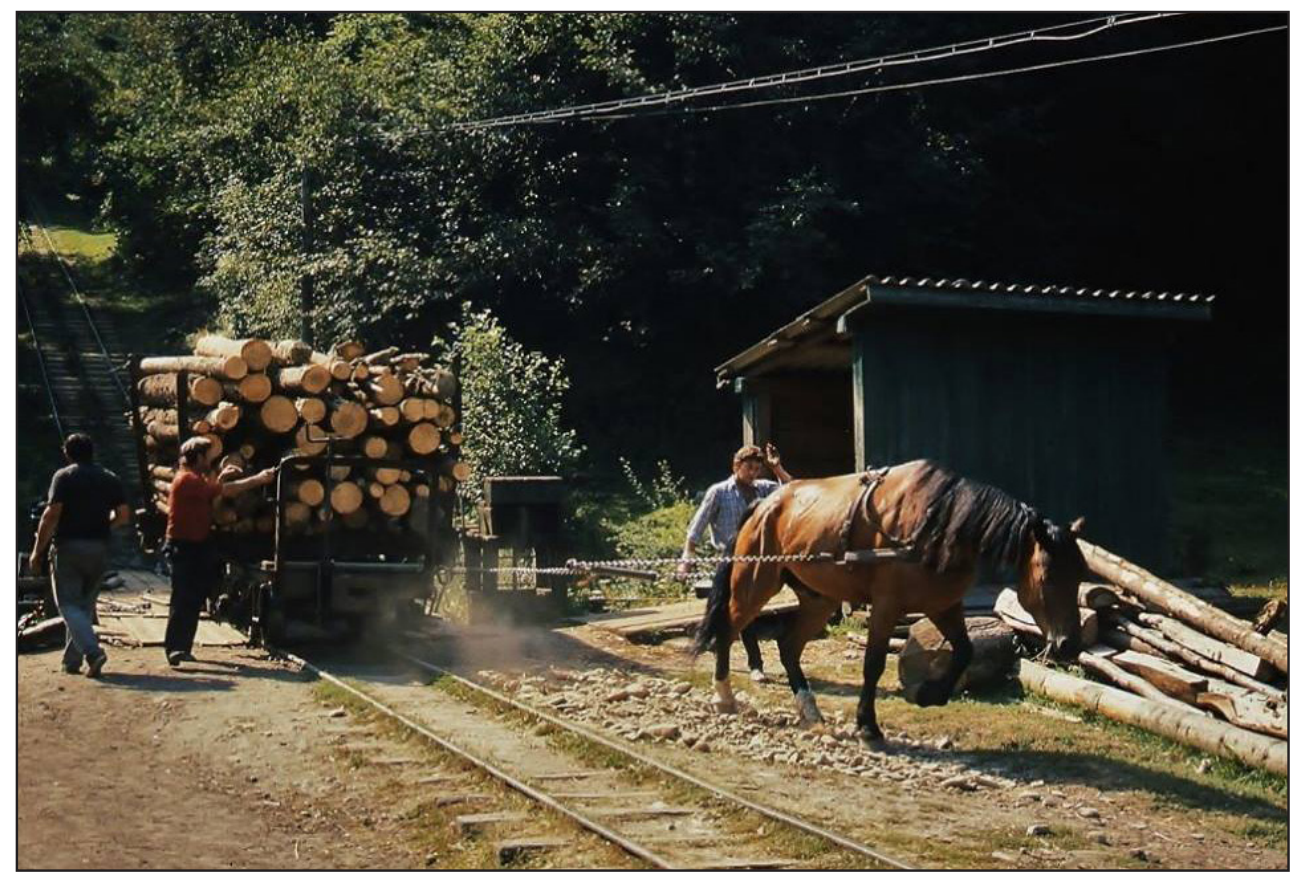

8. kép. Lóvontatás az alsó siklón (1999-es felvétel) 


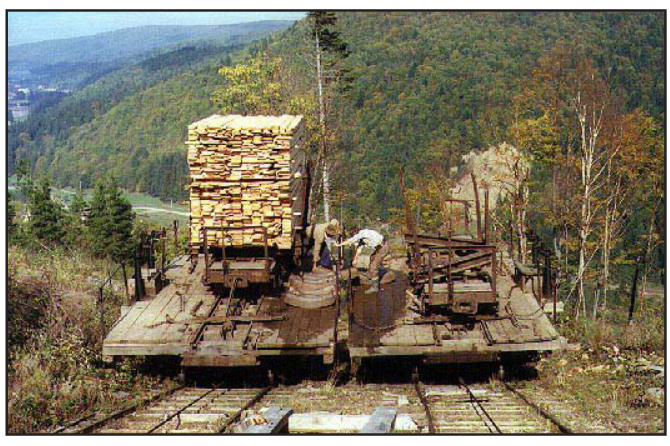

9. kép. Siklóközép ellensúlyokkal (Sáfrány Lajos, felvétele, 1996)

sok Ioanénak nevezték. Úgy beszélik, hogy ez a ló szolgált legtöbb ideig a siklópályán, még félig vakon is tudta a dolgát. A kocsi feltolása egyébként szalasztásos módszerrel történt, a hámot egy horoggal a drukk alvázához ${ }^{20}$ kötötték, a személyzet egyik tagja a lóval megindította a kocsit, a másik pedig a fékálláson állt. Amikor a kocsi kellőképpen felgyorsult, a horgot kiakasztották az alvázból, a kocsi felgurult az állványkocsira, a fékező pedig időben megállította azt (elmondta Gál Sándor és Szabó Csaba).

A deszkákkal, rönkfákkal, szelvényáruval, tűzifával stb. rakott kocsit lóval vagy emberi erővel ráállítják az állványkocsira a felső állomáson, az alsó állomáson pedig az üres truckpárt (pőre kocsi) vagy a hamburgot ${ }^{21}$ (platós kocsit), miután feltolták a kocsikat, rögzítik. Majd ha a rögzítés megtörtént, következett a csöngetés, illetve telefonos engedélykérés, ezután kioldották az állványkocsikat rögzítő reteszeket, ugyanakkor a fenti fékező oldotta a kötéldob fékjeit, s ezzel a rakott kocsi súlya a felső állomásról elindította az állványkocsit lefelé, a másik állványkocsit a völgyből fölfelé. A két kocsi a középállomáson találkozott, platójuk ${ }^{22}$ pereme szinte összeért. Mivel a kilométernél is hosszabb drótkötél súlya mindig az alsó kocsi súlyához adódott hozzá, ezt ellensúlyozandó a felső kocsin ezzel egyenértékű kiegyenlítő súlyokat kellett tartani (ezek voltak a dobfalak fogantyúval felszerelve). Ezeket minden egyes menetben kézi erővel át kellett rakni a középállomáson a lefelé tartó kocsiról a felfelé tartóra. A tolatószemélyzet tagjai mindig a saját pályaszakaszukon dolgoztak a siklón, mert a középállomási váltás után vissza kellett térniük a pályarészletükhöz, valamint az általuk jól ismert és megszokott lóhoz (elmondta Biloklávek Mátyás és Jeney Gyula).

Az adatközlők úgy mesélték, hogy az 1950es évek elején az alsó siklónál a munkások a hídon kézi erôvel dolgoztak, mert a második világháború után évekig nem volt ló. A sikló alatt akkoriban minden kurszánál ${ }^{23}$ hat ember tolta a rakott kocsikat a híd tulsó oldalára, utána pedig az üres kocsit rátolták az állványra, a kocsikat talaborok ${ }^{24}$ segítségével lefogatták, majd ficérre ${ }^{25}$ meghúzták, ez volt a kocsi rögzítésének az elmaradhatatlan munkafázisa, ami nagy felelősséget igényelt. Volt rá eset, hogy a drukk nem volt eléggé rászorítva az állványszerkezetre, és emiatt leesett; olyan nagy volt a zuhanási sebesség, hogy darabokra törött, ilyenkor a munkások fizetése bánta a tévedést. Miután a kocsit ráerősítették, két szerelőmunkás lement az alvázra ${ }^{26}$, és felengedte a kocsit, vagyis ficérrel meglazították, és a csapszeget kihúzták. Ezután a sikló aljáról (alsó sikló) telefonáltak a középsiklóra, ahol szintén telefon volt, és váltóőr, majd hármat csengettek a siklótetőre (felső sikló), ami azt jelentette, hogy készen vannak. A tetőn ugyanilyen múveletet végeztek a szerelőmunkások, csak ők rakott kocsit toltak az állványra. Miután minden készen állt, indultak a kocsik. Középen a váltóőr váltók segítségével irányította a kitérést, és áthúzta az ellensúlyokat a felső állványkocsiról az alsóra. Mikor elindultak a kocsik, mindkét 
féket fellazította a gépész, majd a sebesség szerint fékezet, illetve lazított. Nagyon pontos munkát igényelt ez a feladatkör, mert a nagy sebességtől hamar kisiklott az állványkocsi (elmondta Biloklávek Mátyás).

A sikló karbantartását teljesen a kommandói műhelyesek végezték, sőt a személyzet is a kommandóiak köréből verbuválódott. Olajozták a görgőket, a dobokat, javították az állványkocsikat, cserélték a talpfákat, a hevedereket. Tudták, hova kell sínszeg vagy síncsavar, ők voltak a váltókezelők, tolatók, kisérték a szállítmányt, húzogatták a dobfalakat. Említésre méltó, hogy a fakitermelő vállalat a meglévő két siklópályán kívül még két siklópályát építetett a vranceai havasokban, neruzsai siklók ${ }^{27}$ néven, ahol szintén kommandói munkások dolgoztak. Ezek az ingaforgalmú siklók 1907-1944 között üzemeltek. A munkások rátermettségéről Látó Anna szubjektív monográfiájában az alábbi sorokat olvashatjuk:

„Rendkívül ügyes fickók voltak, helytállni, ugrani egyformán vakmerő büvészmutatvány volt számukra. $S$ még örömük is telt bátorságukban. Nem kevesebb buzgalommal, de kevesebb veszéllyel dolgoztak a góri és kovásznai sikló kocsitologatói is, a „kuplizók”, akik menetidő alatt pihentek ugyan, és történetekkel szórakoztatták egymást és önmagukat, de ha dolgozni kellett, beleadtak apait, anyait." (Látó Anna 1981. 84.)

A kovásznai sikló üzemelése változatos volt. A legforgalmasabb időben, vagyis az első világháborúig, valamint a második világháború utáni gazdasági fellendülés következtében a nagy kihasználtság miatt előfordult, hogy 24 órában üzemelt, akár hétvégén is. $\mathrm{Az}$ adatközlők szerint ebben az időszakban napi 60-70 rakott kocsi is leszaladt. Egy menet 15 percig tartott, amelyből 7-8 perc a középsiklón való pontos fékezéshez, valamint a súlyok átrakásához volt szükséges (elmondta Ferencz János)

Nem volt könnyú az emberek élete. Azonkívül, hogy egész héten az ideiglenes barakklakásokban aludtak, mindig kellett vigyázniuk a zavartalan múködésre is. Az autonóm tartomány megszűntével a község közigazgatásilag átkerült Szilonhoz ${ }^{28}$. 1960-ban Romániában is megszűnt a gőzmozdonyok építése, a resicabányai gőzmozdonyjavító műhelyeket bezárták. Az emlékek szerint ekkortól, ha elromlott a mozdony, Szászrégenbe kellett küldeni fójavításra, a siklón engedték le, s a leküldés nem is jelentett nehézséget. De amikor vissza kellett húzni, az ellensúlyok sem bizonyultak elegendőnek, így még a tetőről is lementek a munkások, hogy szétbontsák a mozdonyt. Darabokban szállították fel. A szállítás úgy történt, hogy a mozdony fökerete külön ment „lábon” a tengelyekkel, víztartályokkal és a sátorral, valamint külön pőrekocsin a kazánja. Történt olyan eset is, hogy minden előkészület ellenére nem sikerült még ebben a formában sem felszállítani a gépet, mert a felső állványkocsi minden nehezékével együtt nem bírta. Ekkor olyan leleményes megoldást találtak ki, hogy a siklótetőre érkező mozdonyhoz hosszú drótkötelet akasztottak, a másik végét ráakasztották az állványkocsi drótkötelére. A mozdony az egyik szabad vágányon elindult Kommandó irányába, így a gép gyakorlatilag besegített a gravitációnak, és felhúzta a lentről érkező mozdonyt. Az utolsó ilyen jellegú szállítás 1993-ban történt, amikor a '47-est, vagyis a Krauss $^{29}$ mozdonyt hozták Kommandóra. A kisebb testű gépezetek felhozatalánál nem volt nehézség, mert a siklón a felső kocsit 20 tonnáig meg lehetett rakni, de a nehezebbekkel sok baj volt. Amikor az utolsó gőzgépet hozták, egy-egy darabja olyan súlyos volt, hogy köveket kellett bányásszanak a kör- 
nyékről a vasutasok, mert fentről a negyven darab másfél mázsás dobfallal megterhelve sem bírta kihúzni a kocsi, és a kövekkel nehezítettek rajta (elmondta Biloklávek Mátyás és Ferencz János).

1944-ben a második világháború végén a visszavonuló német katonák úgy akarták megakadályozni a szovjet haderő előrenyomulását, hogy fel akarták robbantani a siklót. Akkoriban s talán azután is a személyzet olyan önfeláldozó magatartásról és szolidaritásról tett bizonyságot, ami párját ritkította. Szervezetten kifigyelték a hadicselt, így vérontás nélkül megakadályozták a robbantást, megmentve az egyetlen kapcsolatot a lenti és fenti világ között.

1947-ben hatalmas szárazság nyomorította meg még jobban a falut és az embereket, s mintha minden összeesküdne ellenük, még a sikló is lángba borult. A száraz avar lángra lobbant, és alulról fölfelé terjedt a tűz. Mire a munkások, a túzoltók odaértek, az acélkötél elégett, a gépház lángokba állt, az alsó sikló épületei leégtek, és a dobok megsérültek. Hiába védték meg, most mindez kárba ment. De mivel nagyon fontos volt minél hamarabb feljavítani, 14 nap alatt elkészültek vele.

1955-ben a siklótűz megismétlődött, ekkor még a másfél mázsás dobfalnak nevezett ellensúlyok is megsérültek. Valamennyi múhelyi dolgozó és pályaőr ott dolgozott két hétig. A dobfalak javítását Romániában nem vállalták. A műhelyvezető (művezető) rögtönzött esztergapadot szereltetett fel a siklótetőn, a kopásokat feltöltötték, és ott helyben Kerekes Lajos a padon esztergakéssel eldolgozta. Bíró Endre főmérnök Marosvásárhelyről érkezett, hogy hamar megoldja a dolgot. A sikló fontos volt, kellett a fa, mert a háború sok kárt okozott. Akkoriban Kommandó a Maros Magyar Autonóm Tartományhoz tartozott, ami gyakorlatilag kedvezett az ittenieknek,
„A sikló a múlt század utolsó évtizedében készült el, épitését Horn Dávid kezdte és Groedelék fejezték be. Túlságosan is siettek a Dániából rendelt, nem épp első rangú, de viszonylag olcsó gépezet felszerelésével és üzembe helyezésével. Magát az alépitményt sem képezték ki a kötélgörbének megfelelôen, ami Lux Emil mérnök hibájából, de inkább a kicsinyes takarékosság és sietség miatt történhetett, és súlyos balesetet okozott. Az Angliából hozatott drótkötél elszakadt. A baleset századunk elején történt. Azóta is emlegetik. Részletekkel gazdagon megtüzdelt legenda lett belóle. Aki életében elöször utazott a siklón, annak a kötélszakadás történetét, megfelelöen adagolva, mint keserü orvosságot, le kellett nyelnie. Spontán és eleven elöadásban, úgy, mintha a tegnap történt volna, söt ma is megtörténhetne. És mindig a legmeredekebb részen, a legfeszültebb pillanatban, mielött a kocsi elérkezett volna a sikló közepére, a szétágazó sínpárhoz és az utast megnyugvással tölthette volna el a helyén álló, fenséges nyugalommal tisztelgő váltóőr látványa. A siklón utazó újonc kimeredt szemmel figyelt. Ekkor valaki megszólalt tünődő hangon: - Furcsa természetű ez a kötél, nagyon furcsa, el is szakadhat. Megtörtént már. - Mire más hozzáfüzte: - Nem lehet azt kiszámítani, nagyon ravasz. - És kezdetét vette a tökéletes összjáték: abból az egyetlen kötélszakadásból három lett, négy, minden halottból öt-tíz-tizenöt, szaporodtak a rémtörténetek, gyorsuló ütemben elbeszélve, levágott lábak, kerékbe tört derék, esetleg törzsról lenyisszantott fej. Brrr, borzalom! Így ugratták a székelyek a gyanútlan idegent, és úgy belemelegedtek, mintha maguk is hinnék, amit kitaláltak - ... de aztán én úgy szöktem le a kocsiról, bé egyenesen a fák közé vagy tizenkét méterre, éppeg itt, ehelyt... -Több mint húsz éven át rendszeresen utaztam a siklón, efféle történeteket is gyakran hallottam, de katasztrófa soha nem ért. Lehet, hogy elfogult vagyok[...] de én a siklót azóta is a világ legbiztosabb jármüvének érzem." (Látó Anna 1981.21.). 
mert a gépeket itt helyben javították ki. Bíró mérnök a dobok kicserélését lelevelezte valakivel, és fizetség helyett egy vagon sót ígért, ami miatt majdnem bezárták, de a dobokat kicseréltette. Megrendelték az új acélkötelet, de amikor felszerelték, sehogysem akart müködni. Akkor derült ki, hogy fordított fonással kell készítetni, hogy ne tudjon kitekeredni. Még a gépész, Fejér Bandi bácsi sem tudta ezt, pedig 1932-től itt dolgozott. Egyébként Bandi bácsi volt a legjobb gépész, és nagyon értett a karbantartáshoz is. Ezenkívül soksok évig ott dolgozott, és balesetmentesen kezelte a siklót (elmondta Jeney Gyula).

A kommunista rendszerben előre le kellett jelenteni, hogy milyen mennyiségű árut rendelt az élelmiszer-raktáros, mert fel kellett készüljenek a tetőn, vagyis úgy helyezték a rakományt, hogy tudja felhúzni az alsót. Sokszor megtörtént, hogy kevesebb szerepelt a bárcán ${ }^{30}$, s nem bírta a felső, ilyenkor a tetőről a munkások cipelték a dobfalakat, s ha már ez is elfogyott, addig mentek gyalog, ameddig elérték az alsó kocsit, és leszedtek a zsákokból. Ha netalán kilyukadt valamelyik, azt megfizettették velük. Amikor az acélkötelet ki kellett cserélni, főjavítást végeztek a szerkezeten - ezt meg kellett rendelni, s pár napba beletelt, amíg megjött az engedély, és végeztek a munkálatokkal. Ilyenkor gyalog közlekedtek az emberek, és annyira felgyűlt az áru, hogy még éjjel is engedték a kocsikat. Ha nyáron történt valami a siklóval, a bükkszállítmányt a kommandói vasútállomáson vízzel locsolták, mert ha megszáradt és elhasadozott, visszaküldték, s ezt is a munkások bére bánta meg (elmondta Biloklávek Mátyás).

A munkások számára legnehezebb a téli időszak volt. Jó tudni, hogy Kommandón általában hat hónapig tart a tél, és nemegyszer 1,5-2,5 méteres hó esik. Ilyenkor minden

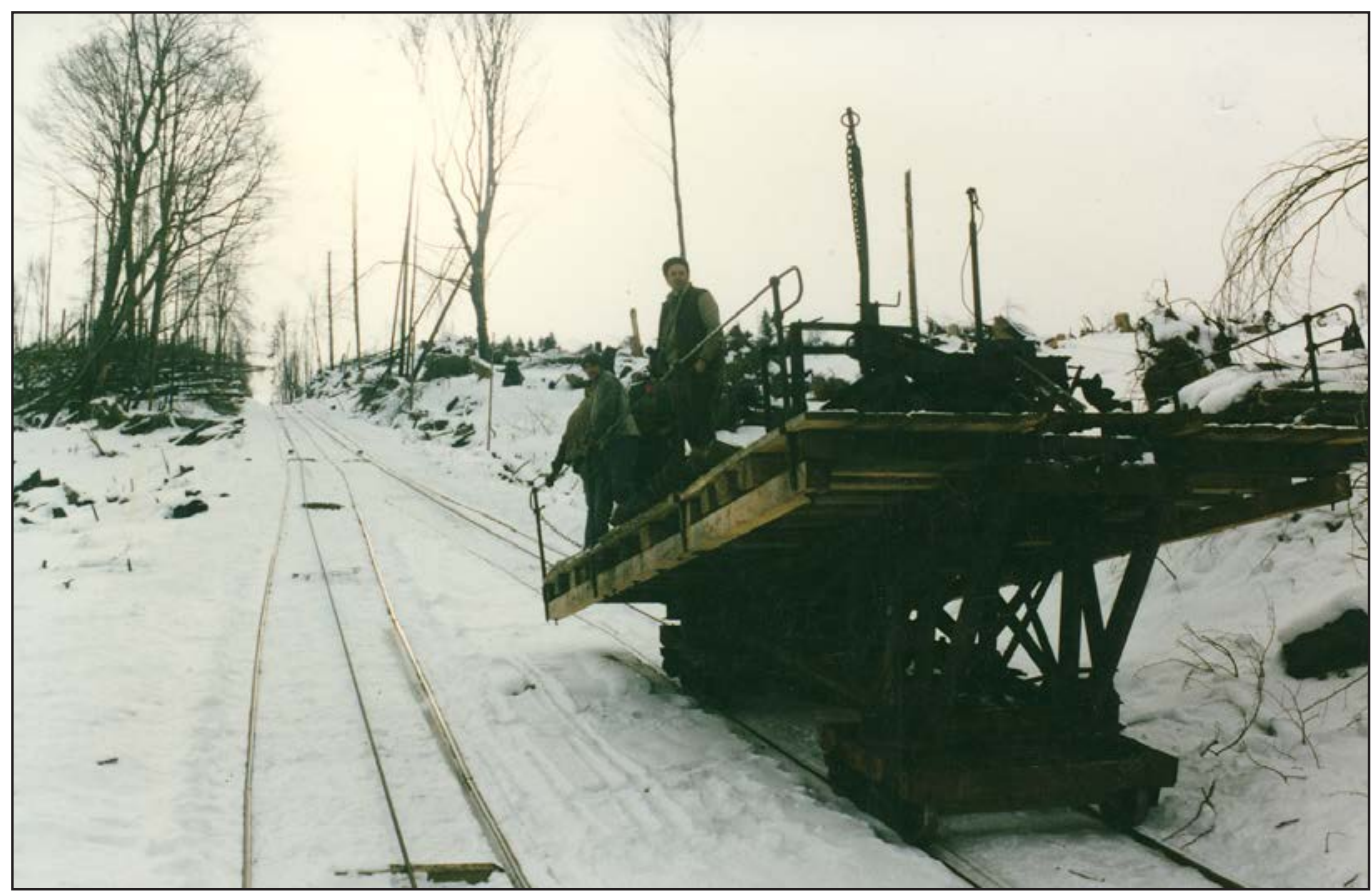

10. kép. A siklópálya 1999-ben 
munkás, beleértve a gépészt is, hólapáttal hajnalban kezdte a napot, mert amire megjött az első rakomány, a siklópályát ki kellett takarítani, a mozdonyra sokszor hóekét szereltek, de a siklónál ilyent nem lehetett alkalmazni.

Az 1960-as évek végén még állt a siklótetőn az a tábla, amelyen a következő felírat szerepelt: „Komandó-Kovászna sikló. Tervezte: Lux Emil. Épült: 1888-1890. A sikló napi teljesítménye: 30 kocsi rakomány, $10 \mathrm{~m}^{3} \mathrm{fa}=$ $300 \mathrm{~m}^{3}$."

A siklópálya világításával kapcsolatosan az adatközlőktől a következőket tudhattuk meg: kezdetben sötétedés után nem működött a sikló, az 1900-as évek elején fáklyákat helyeztek az állványkocsira, majd karbidlámpával világított a személyzet. A faipar fénykorában (1924) sötétedés után Petromax benzinlámpákat szereltek fel az állványkocsikra, és ezekkel világítottak a sötétben. Az 1950-es évek elején az alsó siklóra hozattak egy Rákosi motort kis generátorral, és megvalósították a villanyvilágítást a siklópályára. Az 1970-es években felhozták ide is a magasfeszültségű villanyhálózatot Kovásznáról (elmondta Biloklávek Mátyás).

Az 1947-es siklótűz alkalmával komolyan fontolóra vették azt (lévén, hogy sokan szenvedtek balesetet a siklón az évek során), hogy az utasok részére a szomszédos Kopasz nevű hegyre, amely sokkal lapályosabb, egy 13 km hosszúságú keskeny nyomtávú vasutat építetnek, amelyen „fogaskerekű” járattal megoldható lett volna az utasok biztonságos szállítása a siklótetőre (Kinda István Pozsony Ferenc 2007).

A kommunizmus éveiben már nem akadályoztatta a vezetőség a siklón a személyszállítást, s ezért a kocsirakományok súlya $10000 \mathrm{~kg}$-nál nem lehetett több (5 tonna drukkonként), mert kb. 2000 kg az emberek súlyára volt megengedve, ha nem bírta a felső kocsi az alsót (legtöbb esetben felfelé volt gond), leszállították az utasokat. Az adatközlő emlékei szerint egy pár drukk rakománya 10-12 $\mathrm{m}^{3}$ fa lehetett, s ennek megfelelő súlyarányban helyezték az alsó siklóállványra az üres drukkokat, platókat, hamburgokat, bárkákat. ${ }^{31} \mathrm{~A}$ drukkból általában egy pár elegendő volt, ha jó volt a fa. Az 1961-es széltörés után a száraz faanyagnak nem volt súlya, vagyis nem volt meg a fékszázalék, s ekkor három darab üres féldrukkot kellett rátenni az alsó állványra (ennyi fért fel összenyomva), ebből az egyiket mellékvágányra terelték (kézzel tolták) a tetőn, s miután meglett a párja, leellenőrizte a revizor, hogy megfelelö-e, ha nem, krétával megjegyezte, és kijavítás után

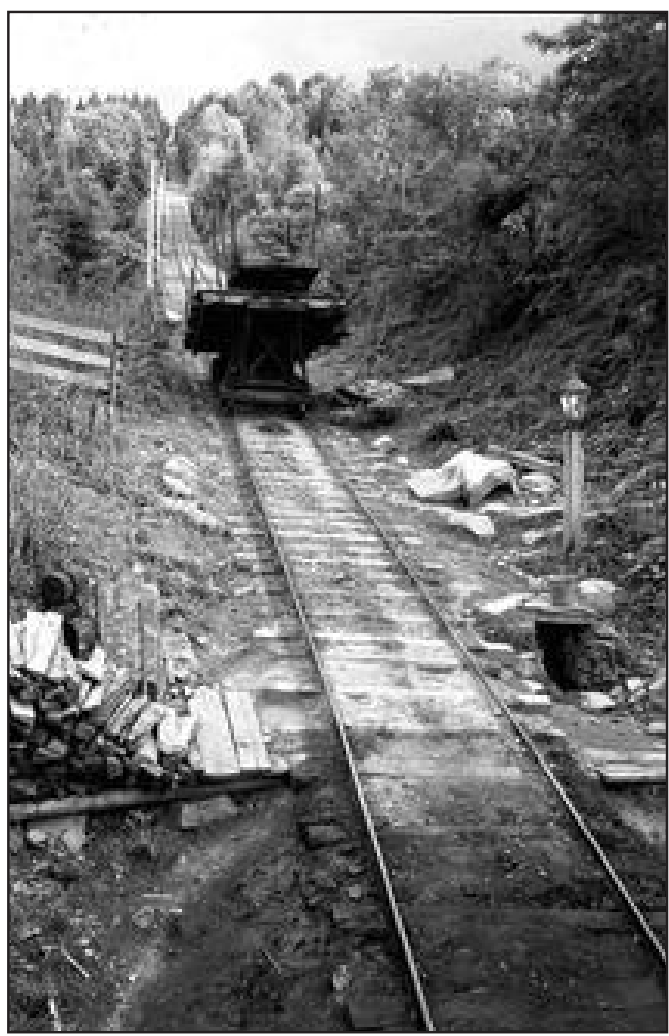

11. kép. Az első Petromax világítótest 
vitték fel a kommandói fürészgyárba. A hamburgokat meg kellett rövidíteni, mert nem fértek fel a siklóállványra. Ezekre főleg méterfarakomány került (elmondta Biloklávek Mátyás).

Még az 1970-es évek elején is közlekedtek a kommandóiak a siklón, aztán az út miatt - 1969-ben építették meg a Kovászna-Kommandó közötti makadámutat - ismét letiltották a személyszállítást, de sürgősség esetén még az 1980-as évekig bárki felülhetett az állványkocsira a szállítmány mellé. Természetesen mindenki vállalta saját magáért a felelősséget, ha baleset történt volna vele, senkit nem vontak volna kérdőre. Az elbeszélőnek és nagyon sok más kommandói embernek a sikló mindig biztonságos jármúnek számított, hiszen itt nőttünk fel, évekig ezen utaztunk, és soha eszükben sem jutott a félelem.

Az utolsó siklótűz, vagyis a harmadik a sikló életében 1996. május 19-én tört ki. Jórészt minden megégett, de még ekkor is újjáépítették, mert az 1995-ös nagy széldöntés - 1995. november 5-én 2,5 millió köbméter szálfát döntött ki a szél - utáni fákat el kellett szállítani valahogy. Ekkor az újraépítésen az utolsó vasúti személyzet is részt vett, majd 1999. november 1-jén a szállítási vállalat csődje végleg megállította a siklót is. És ezzel az ipartörténeti jellegű sikló sorsa is megpecsételődött. Széthordták, tönkretették, a felszerelés nagy részét ócskavasnak adták el. Erről így ír a sepsiszentgyörgyi Háromszék címú napilap:

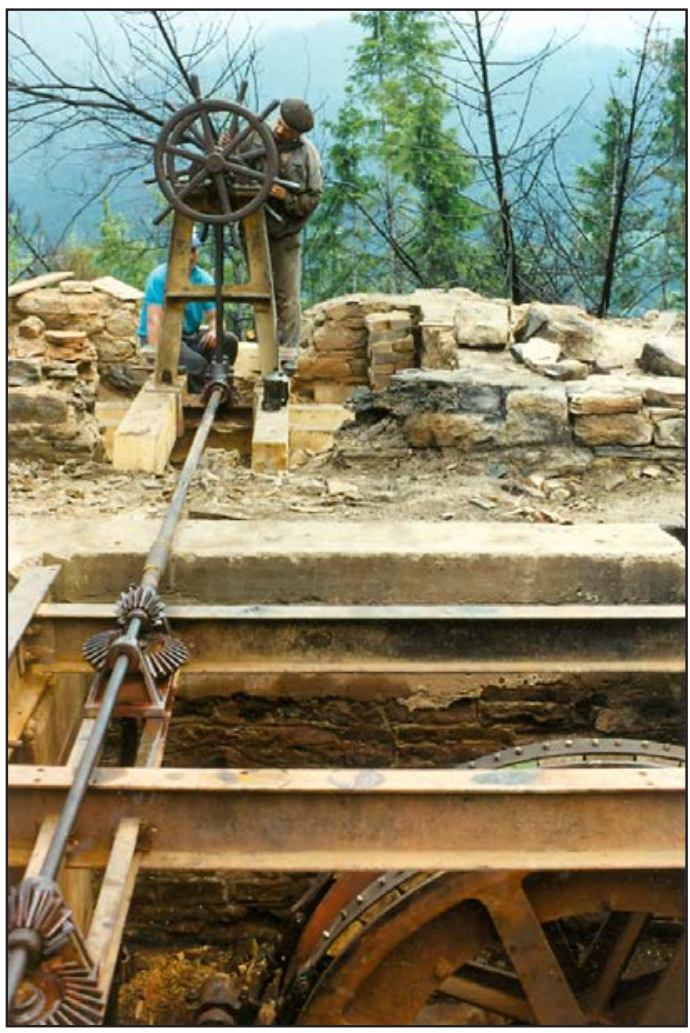

12. kép. A tûz után, Debreczi Károly (1996. május) 


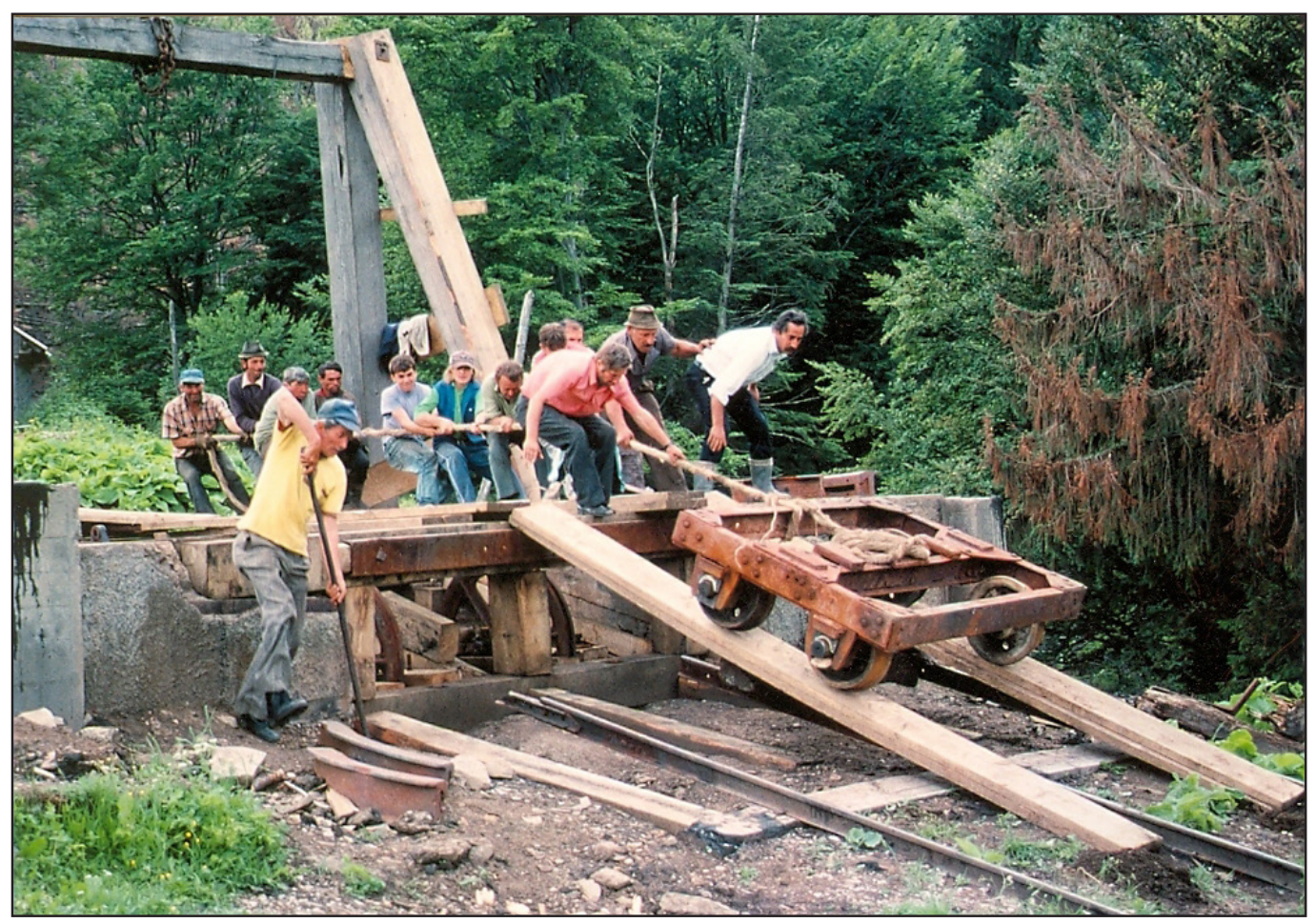

13. kép. Javítási munkálatok 1996-ban

„[...] patthelyzet alakult ki, ugyanis az Apor család a 10-es törvény értelmében vindikálja az ipartörténeti múemléket, így, amíg a per el nem dől, nem lehet lépni az ügyben. Ilyen körülmények között a sikló és a kisvasút ügyében pillanatnyilag nem tudunk egyebet tenni, csak azt, hogy örizzük. Ennek ellenére, amióta felemelték az ócskavas árát, minden mozgatható vasdarabot elloptak a feketézók. Pedig az örök folyamatosan terepen vannak, de a kovásznai vasútállomás és a sikló, illetve a sikló és Kommandó között nagy a távolság, s a tolvajok kilesik a megfelelő pillanatot, és úgyis ellopják, ami mozdítható. A gond az, hogy a hasznavehetetlen rozsdás bádogok mellett olyan pótolhatatlan alkatrészeket is elvisznek, amelyeket több mint száz évvel ezelőtt gyártottak, s ma már nincs rajz, ami szerint újat lehetne készíteni."(Bodor János: Interjú Barthos Istvánnal, Háromszék, 2003. május 29. 3.)

\section{A siklópálya jelene}

Napjainkban, ha alaposabban szétnéznének a szakemberek, azt állapítanák meg, hogy az eltelt pár év alatt még a maradékot is széthordták, mert a sikló romokban hever, a híd beszakadva, az egyik állványkocsi évekig ott hevert a híd alatt, majd kiemelték, de jelenleg nem tudni, hogy hol van. A sínek lógnak a levegőben, elhordták a kötelet, a sínszegeket, az alátéteket, a hevedereket, az orsókat, a csapágyakat, sőt épületek is eltûntek, még a váltókat is kitépték, $\mathrm{s}$ a kommandói ember, ha arra jár, elfordítja a fejét, hogy ne lássa, mivé lett az, ami egykor a lételemünk, a büszkeségünk volt. Gyakorlatilag semmi nem maradt abból, ami Kommandót és Kovásznát 


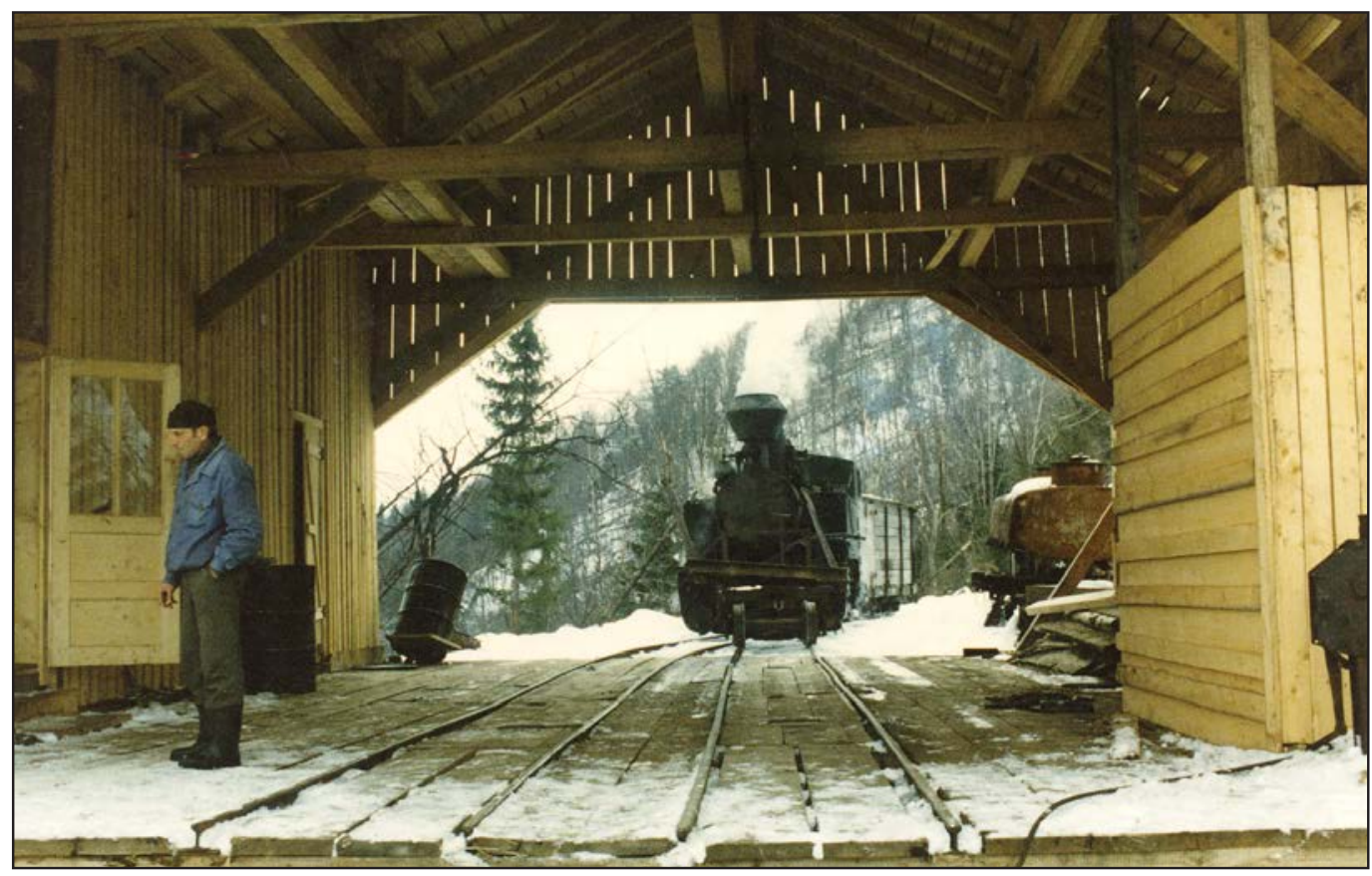

14. kép. Az újraépített siklótetô. 1999-es felvétel

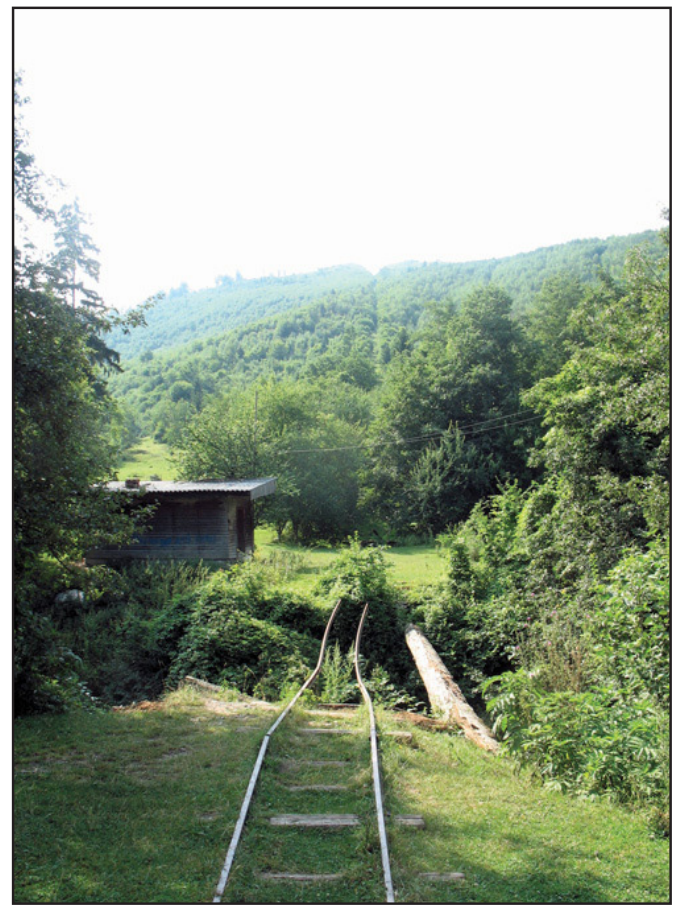

15. kép. Siklóalja 2008-ban az európai turisztikai vérkeringéshez kapcsolhatta volna. Hiába van műemlékvédelmi jegyzéken minden, a fémtolvajok még mindig dézsmálják az ipartörténeti maradványokat. A területi jogviszonyok még napjainkban is tisztázatlanok, ezért bármi megtörténhet.

Mindent összegezve attól kell félnünk, hogy addig tart ez az enyém, tied, övé, mienk jogvita, amire még a muzeális tárgyaknak sem marad nyoma. Sokan a kommandóiak közül, de mások is úgy jellemzik a sikló jelenlegi állapotát, hogy néhány évig megmarad a helye, mert erősen elkezdődött a pályatesten a természet regenerálódása. Az európai szinten egyedinek számító siklópályából gyakorlatilag semmi se látható - a kifüggesztett fotón kívül -, csak a sínszálak egy-egy része, s az is csak közelről és addig, ameddig az erdő visszaveszi azt, ami az övé volt. 


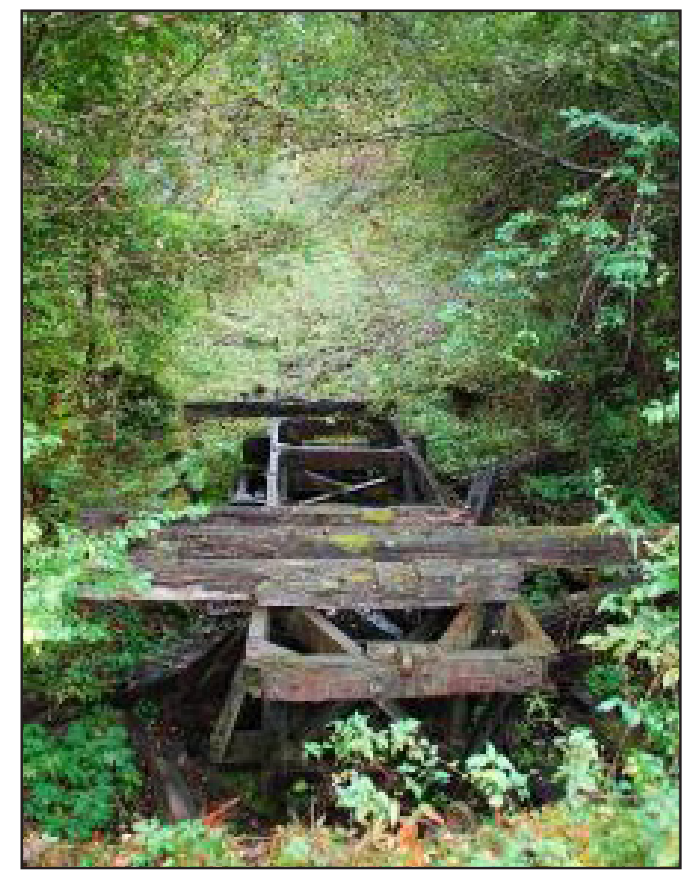

16. kép. A sikló maradványai, napjainkban

\section{Jegyzetek}

1. Kommandó község a hajdani Háromszék vármegye, ma Kovászna megye legmagasabban fekvő települése (tengerszint fölötti magasság:1068 méter), valamikor a 2. székely határőrezred állomáshelye volt, pontosabban parancsnoksági székhely, innen ered a megnevezése. A civilek lakta település 1889-ben ipartelepként létesült, egyszerre kezdett el lélegezni a gőzfürészgyárral, a kisvasúttal és a siklóval.

2. Kovászna - fürdőhely Kommandótól 18 km-re, 1952-től város, ma Kovászna megye harmadik legnagyobb települése.

3. Az elsőt Lyon és Croix Rousse között 1862ben építették - ez ingaforgalmú sikló volt -, a másodikat Budapesten 1868-1870 között, Budai Hegypálya néven (kétsínes, kötélvontatású, gőzhajtású sikló), tervezte Wolfahrt Henrik, a példa Lyonból származott, gróf Széchenyi Ödön építtette. (Acsárdi Ignác 1893. II. kötet 1560.)
4. Horn Dávid - felvidéki zsidó üzletember, mérnöki diplomával és sokoldalú nyelvtudással rendelkezett. 1886-ban 14582 kataszteri hold erdőt vásárolt Kommandó környékén. Ő rakta le nemcsak a település, hanem a háromszéki faipar alapjait is.

5. Groedelék - zsidó üzletemberek, akik megvásárolták Horn Dávidtól az Erdélyi Erdőipar néven működő iparvállalatot.

6. Gyulafalva - településnév. Kommandótól délkeletre, 1888-tól 1940-ig. Napjainkra csak a neve maradt fenn.

7. állványkocsi - a siklópályán közlekedő magas építmény megnevezése, két részből áll: állványból és padozatból.

8. rolnik - görgők, ez esetben rézből készültek.

9. tirefon - csapszeg.

10.góri sikló - az Erdélyi Erdőipar Rt. 1893ban a Górnak (1778 m) nevezett hegyre (Vrancea megye) siklópályát építtetett, amely 1931-ig múködött. Ez egy kétsínes gőzhajtású sikló volt. 1904-ben készített színes képeslapokon a szerkezet úgy szerepel, mint Kommandó érdekessége.

11.talpas sín - hengerelt acélból készült, széles talpú Vignol-sín. Az egyes vasutak sajátosságai, illetve felépítményfajták szerint többféle sínrendszert használtak. A Vignoles széles talpú sín (a feltalálójáról van elnevezve) elterjedt volt Európában, másként Góliát-sínnek is nevezték, a síntalp szélessége $140 \mathrm{~mm}$, ez biztosította, hogy a sín stabilan álljon. Teherelosztó elemként a sínfej tetején keletkező igénybevételnek a töredékét adja az alátétlemeznek, illetve az aljnak (Urbán Lajos 1984).

12. muff - fékpárna (pamutból készült).

13. fékcsintura - fékszalag (vasból készül kb. $20 \mathrm{~cm}$. széles).

14.szilfatuskó - szilfából készített fékszerkezet (utóbb cserefából készítették).

15. kursza - itt: menetidő.

16.pőrekocsi - truck. 
17. csihányspárga - csalánból font vastag kötél, eredetileg lenből készült, később cserélték a csalánra.

18. mánus - mutató.

19. sámli - fékülés.

20. drukk (truck) - pőrekocsi.

21. hamburg - Hamburgból hozott vasúti kocsik egységes megnevezése, itt: deszkázott nagyobb kocsi.

22. plató (platós kocsi) - az angol platform után vasúti kocsik egységes megnevezése.

23. kursza - fuvar.

24. talabor - nagyméretű, láb alakú vas csapszegekkel ellátva.

25. ficér - csapszorító kar.

26. alváz - alépítmény, az állványkocsi alsó része.

27. Neruzsa (Naruja) - havas és településnév Vrancea megyében.

28. Szilon (Siriu) - község Szitabodza szomszédságában (Buzău megye).

29. Krauss - CFF 763-247-es pályaszámú mozdony, a müncheni Krauss \& Co. gyártotta 1916-ban (Papucs András 2011. 22.).

30. bárca - fuvarlevél helyies neve

31. bárka - szeneskocsi.

32. revizor - vagonellenőr.

\section{Felhasznált irodalom}

Acsády Ignác dr. (szerk.): Az Athenaeum kézi lexikona I-II. A tudományok enciklopédiája különös tekintettel Magyarországra. Az Athenaeum Irodalmi és Nyomdai Társulat kiadása, Budapest, é.n. (1893) II. kötet 1560.

A kovászna-gyulafalvi iparvasút megnyitása. Székely Nemzet VII. évf. 183. sz. 1890. november 27. 3.

Baross Gábor magyar kir. miniszter levelezése: Kérvények (1887-1892). Magyar Nemzeti Levéltár Országos levéltára, P. 111, A/4, 12,7 fm.

Bodor János: Interjú Barthos Istvánnal. Háromszék, 2003. május 29. 3.

Gyárfás Győző: Közlekedési viszonyok. In: Pótsa József (szerk.) Háromszék vármegye. Emlékkönyv Magyarország ezeréves fenn- állása ünnepére. Jókai Nyomda Rt., Sepsiszentgyörgy, 1899.

Györffy Kálmán: A sikló egykori gépésze. Komandói képeslapok. Megyei Tükör, Sepsiszentgyörgy, 1975. június 6. 4.

Látó Anna: Honvágyam hiteles története. Kriterion Könyvkiadó, Bukarest, 1981. 84.

Monografia Intreprinderii Forestiere din Comandău până la 13 noiembrie 1958. (Magántulajdon)

Nagy Jenő (szerk.): A Kovászna-Komandó Erdei vasút és siklópálya. Mester Nyomda, Budapest, 2002.10.

Papucs András: Erdei iparvasutak Orbaiszéken. In: Kinda István-Pozsony Ferenc (szerk.): Orbaiszék változó társadalma és kultúrája. Cova Print Nyomda, Sepsiszentgyörgy, 2007. 127-140.

Papucs András: Vasúti vontatójármúvek Kovásznán és Kommandón. Tipographic Nyomda, Csíkszereda, 2011. 22.

Rácz István (szerk.): Tanulmányok Erdély történetéről. Szakmai Konferencia Debrecen 1987. okt. 9-10. Csokonai kiadó, Debrecen, 1998.

Rosta István (szerk.): Fejezetek a magyar technika történetéből (Szent István korától a XX. századig). Nemzeti Tankönyvkiadó, 1995.

Sümegh Ignác: Erdei iparvállalatok Háromszék Vármegyében. Erdészeti Lapok 1898. Szerk. Dr. Bedő Albert - ÁK. 1249 (Országos Erdészeti Egylet könyvtára) Budapest, 37. évf. X. füzet, 1909-1910.

Szabó Mária: Kommandó monográfia. T3Könyvkiadó, Sepsiszentgyörgy, 2004. 47-48. Urbán Lajos: Vasúti Lexikon. Műszaki Könyvkiadó, Budapest, 2004.

\section{Adatközlők}

Biloklávek Mátyás (1935-2014) - Kommandó

Ferencz János (1937) - Kommandó

Gál Sándor (1959) - Kommandó

Jeney Gyula (1927-2015) - Kovászna

Péter János (1953-2016) - Kommandó

Szabó Csaba (1955) - Kommandó 